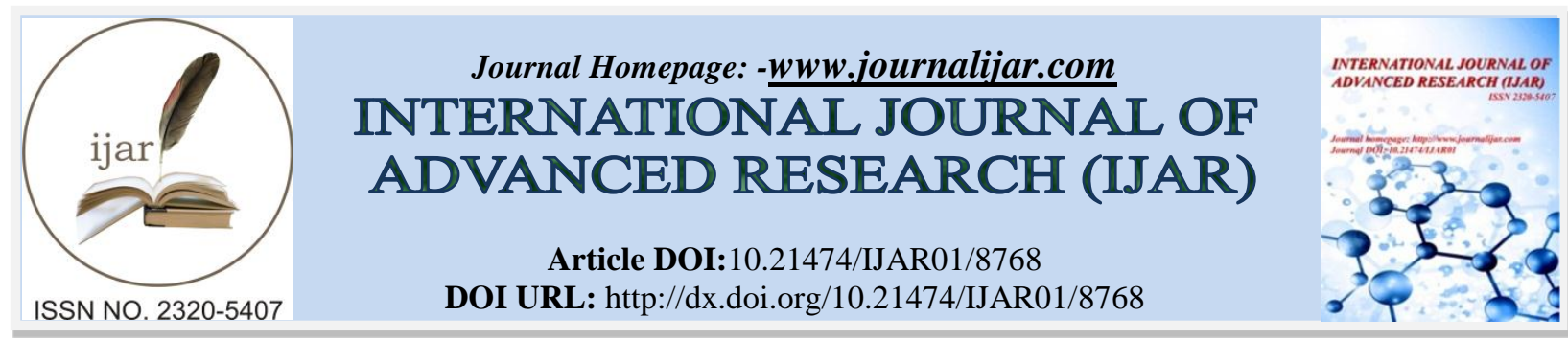

RESEARCH ARTICLE

\title{
CONCEPT OF NOVELTY IN INDIA AND US ALONG WITH CRITICAL ANALYSIS OF AG NOVARTIS CASE.
}

Shivani Bhushan ${ }^{1}$ and Dr.Vijay srivastava ${ }^{2}$.

1. Student (B.B.A.L.L.B. FINAL YEAR) Law college Dehradun, Uttaranchal University, Dehradun. U.K.

2. Assistant Professor, Law College Dehradun, Uttaranchal University, Dehradun. U.K.

\section{Manuscript Info}

Manuscript History

Received: 20 January 2019

Final Accepted: 22 February 2019

Published: March 2019

\section{Abstract}

Copy Right, IJAR, 2019,. All rights reserved.

\section{Introduction:-}

The concept of awarding patent emerged to promote the inventions in all the fields as patent is considered as a protection provided to the true and first inventor of a product, or a process against it being copied, by any other person without their prior authorisation or consent.

In India the grant of patent is regulated by the patents act of 1970 along with the patents rules, 1972, which came into force on $20^{\text {th }}$ April, 1972.

A patent is an exclusive right granted to an invention. Generally speaking, a patent provides the patent owner with the right to decide how-or whether-the invention can be used by others. In exchange for this right, the patent owner makes technical information about the invention publically available in the published patent document.

According to patents act, 1970, "patent", means a patent granted for any invention under this act. ${ }^{1}$

A patent for an invention is the grant of a property right to the inventor, issued by the United States Patent and Trademark Office. Generally, the term of a patent is 20 years from the date on which the application for the patent was filed in the United States or, in special cases, from the date an earlier related application was filed, subject to the payment of maintenance fees. U.S. patent grants are effective only within the United States, U.S. territories, and U.S. possessions. Under certain circumstances, patent term extensions or adjustments may be available. ${ }^{2}$

\section{Historical Development of Patent Law in India}

The act VI of 1856 was the first ever legislation in India related to the patent system. After India gained its independence, the need was felt to modify and amend the patent and design act 1911, in order to meet the substantial changes in the political, economic changes of the country and therefore a committee under the chairmanship of justice (Dr) Bakshi Tek Chand was constituted, in order to review the patent law and make report suggesting necessary changes. On the basis of the recommendations of the abovementioned committee a bill was introduced in

\footnotetext{
${ }^{1}$ Bare act patent act 1970

${ }^{2} \mathrm{https}$ ://www.uspto.gov/patents-getting-started/general-information-concerning-patents (last visited on 5th march. At 23:33 pm)
} 
the parliament in 1953 (bill no.59 of 1953). However the bill was did not receive the consideration of the government and it was lapsed. ${ }^{3}$

Later in the year, 1957, the government of India appointed a committee under the chairmanship of Justice Rajagopalachari Iyyengar, to revise the patent law, to suggest necessary changes in order to meet the national interest.

The committee submitted its report which was divided in two parts and on the basis of the report of the committee; a bill was introduced in the Lok Sabha in $21^{\text {st }}$ September, 1965, which later on lapsed. It was in the year, 1967; again a bill was presented before joint parliamentary committee and thereafter, the patents act, 1970 was passed. ${ }^{4}$

The act of 1970 was further amended in the year 1999, then later on amended in the year 2002, i.e. patents (amendment) act, 2002 along with it; patent rules 2003 also came into force.

Later the patent act of 1970 was amended for the third time in the year 2005, through patent (amendment) ordinance, 2004.

\section{Historical Development of Patent Law in United States}

The Unites States patent law was first established in the year 1790, where the patent protection was provided for the maximum duration of 14 years on "useful, important and new inventions". 5

The principles of patent act of 1790, was derived from the patent law of Venice, established in 1474, where the first patent law was created and enforced. ${ }^{6}$

The patent act of 1790 was further repealed by the act of 1793 . The act of 1793 was further repealed by the act of 1836, which led to establishment of US patent office in the state department. The US patent office was responsible for the examination of the patent applications. ${ }^{7}$

It was in the year 1859, the definition of US patent act was extended, and now the patent are required to be "nonobvious" to other professionals in the same field. ${ }^{8}$ Further in the year 1950 there were significant changes made to patent law, where the innovators have to provide for a detailed description of their innovation and define the basis for its infringement, if the situation may require. ${ }^{9}$

Currently in the United States, the patent is regulated by the title 35 United States Code. Further, the congress on $29^{\text {th }}$ November, 1999 enacted the American Inventors Protection Act, 1999, which led to further revision of patent laws in the United States. ${ }^{10}$

\section{Concept of novelty}

Novelty means the quality of new, original or unusual. ${ }^{11}$ Any invention, wheather it is a product or a process, in order to obtain patent protection must fulfil three basic requirements, they are:

1. The invention must be novel

2. The invention must involve an inventive step (inventiveness)

3. The invention must be useful, in other words it must capable of industrial application. ${ }^{12}$

\footnotetext{
${ }^{3}$ www.ipindia.nic.in/history-of-indian-patent-system.htm(last visited on, $5^{\text {th }}$ march, 2019 at 7:30 pm)

${ }^{4}$ Ibid

${ }^{5} \mathrm{https}$ ://onlinellm.usc.edu/blog/history-of-patent-law/ (last visited on $5^{\text {th }}$ march, at 23:20 pm)

${ }^{6} \mathrm{https} / / /$ patent.laws.com/patent-law-history (last visited on 5th march, at 23:28 pm)

${ }^{7} \mathrm{https}$ ///essaylead.com/history-and-effects-of-itellectual-property-laws-essay/ (last visited on $6^{\text {th }}$ march, at 00:50 am)

${ }^{8}$ https://onlinellm.usc.edu/blog/history-of-patent-law/ (last visited on $6^{\text {th }}$ march, at 00:53 am)

${ }^{9} \mathrm{https} / / /$ onlinellm.usc.edu/blog/history-of-patent-law/ (last visited on $6^{\text {th }}$ march, at 00:56 am)

${ }^{10} \mathrm{https} / / / \mathrm{www}$. uspto.gov/patents-getting-started-/general-information-concerning-patents\#heading-3 (last visited on $6^{\text {th }}$ march, at 01:03 am)

${ }^{11} \mathrm{https} / / /$ en.oxforddictioneries.com/definition/novelty (last visited on 6th march, at 17:20 pm)

${ }^{12} \mathrm{Pfc}$.org.in/ach/novel.htm (last visited on $6^{\text {th }}$ march, at 17:27 $\mathrm{pm}$ )
} 


\section{Novelty under Us Patent Regime}

Any invention will not be capable of being patented on the following grounds:

1. If the invention was already patented, described in printed publication, or in public use on sale, or otherwise available to the public before the effective filling date of claimed invention; or

2. The claimed invention was described in the patent issued by the US, or in an application for patent published or deemed published by US, in which the patent or application, as the case maybe, names another inventor and was effectively filled before the effective filling date. ${ }^{13}$

Therefore, any inventor would receive the exclusive right over the claimed invention only when the invention is new and original and has not fallen into public domain.

Granting a patent on any invention that is already known to the society would actually place a constraint on the society in respect of the use of known information without providing any return or benefit. The line between what belongs to the society and what can be withheld from it, is to a large extent drawn by the notion of novelty. Therefore, in patent law, requirement of novelty is one of the most recognised principles. ${ }^{14}$

Any invention, whether a product or a process must possess the feature of novelty, which means it must be new and must not have fallen into public domain. If such invention contains anything already known to the society or public at large, patent cannot be granted as such information or invention belongs to the public and hence lacks "newness" or "novelty". US code sec 101, 102 and 103 deals with novelty, anticipation and non-obviousness.

\section{Novelty under Indian Patent Regime}

Novelty under the indian context signifies that the invention must not be anticipated by publication in any document, or used or known in India or anywhere else in the world before the filling date (priority date); which technically means that the invention must not have fallen into public domain or that it does not form part of the state of art, and the invention has not been claimed in any claim of any other complete specification claiming other priority date and published on or after the priority date of the application ${ }^{15}$.

\section{Test of Feature of Novelty In Claimed Invention}

In order to determine whether an invention has the feature of novelty, the patent office examine the patent and nonpatent literature to find out whether the invention has been anticipated by any prior publication or claim. Moreover, novelty is examined before the inventive step as the creative contribution of the inventor can be assessed only by knowing whether the claimed invention is novel. ${ }^{16}$

In Gujarat Reclaim and Rubber Products ltd. v. Kamani Metallic Oxides ltd (1983 PTC 105 (Bombay), the opponents made a plea that the claimed invention of the applicant already existed in the public knowledge, therefore they ought to prove before the court that the claimed invention was already in public knowledge before date of filling of application. However, the documents cited as evidence by the opponents were not sufficient, as they do not anticipate the applicant's invention. ${ }^{17}$

The invention in order to satisfy the criteria of novelty, the invention in particular must be novel. If the invention comprises of various components and if any of the components are already known then in such case the entire invention will be considered as lack of novelty. Moreover, if the purpose of the invention or its result is new, it will not be considered sufficient. Novelty must therefore exist in the mode of application. ${ }^{18}$

\section{Comparision of Novelty in India and Us}

\footnotetext{
${ }^{13} \mathrm{https}$ //uspto.gov/patents-getting-started/general-information-regarding-patents\#heading3 (last visited on 18:01)

${ }^{14} \mathrm{https} / / / \mathrm{www} . w i p o . i n t / e x p o r t / s i t e s / w w w / s c p / e n / n o v e l t y / d o c u m e n t s / 5 p r o v . p d f$ (last visited on 7th march, at 20:18 $\mathrm{pm})$

${ }^{15}$ Ibid

${ }^{16}$ www.ipindia.nic/writereaddata/portal/IPOguidelinesmanuals/1_59_1_15_wo_ga_34china.pdf (last visited on 7th march, at 21:45 pm)

${ }^{17}$ Ibid

${ }^{18}$ https://www.worldwidejournals.com/global-journal-for-research-analysis-

GJRA/recent_issues_pdf/2015/may/may_2015_1445945679_80.pdf (last visited on 7th march, at 23:00 pm)
} 
According to Indian Patents Act, 1970; an invention in order to receive patentability must be new, novel and must involve inventive step. Whereas, US code, sec 102 specifically mentions the conditions that would prevent from obtaining patent. These limitations are therefore applicable universally.

Anticipation is a condition which is a ground for rejection of any patent. Therefore, rejection based on Sec 2(1) of British aAct and sec 102 of the US Code are most commonly based on printed document. Furthermore, anticipation by way of prior publication is supposed to be in the form of a printed publication, which would enable any person skilled in art to comprehend the invention. ${ }^{19}$

AG Novartis v Union of India ${ }^{20}$, J. Aftab Alam, Ranjana Prakash Desai

Brief facts of the case: Jurg Zimmerman, a medicinal chemist, invented a number of derivatives of N-Phenyl-2 in a free base. One of those derivatives includes imatinib, which has anti-tumoural abilities and can be used in the preparation of anti tumoural drugs. The derivatives imatinib received patent in US and was granted patent on $28^{\text {th }}$ may, 1996(application made on $28^{\text {th }}$ April, 1994)..$^{21}$

Novartis (hereinafter referred as "appellant"), discovered imatinib mesylate in beta crystalline form and claimed for patent inUS. It initially received opposition by the patent office but later on patent was granted in US. ${ }^{22}$ Appellant also applied for patent in India on $17^{\text {th }}$ July, 1998 and further claimed in invention that beta crystal form of imatinib has beneficial properties, such as:

1. More beneficial flow properties

2. Better thermodynamic stability

And these properties make the invented product "new". 23

The issue before the court was to examine whether the invention satisfies the criteria of sec 2(1) (j) and (j a), along with sec 3(d) of the Patents Act, 1970 and furthermore whether the product has technical advancement and is "nonobvious" to person skilled in that art. The court has to strike a balance between the need to promote research and development in science and technology and to keep private monopoly. The court was reminded of its duty to uphold the rights granted by the statute, and the court was also reminded that any error of judgement by it will put lifesaving drugs beyond the reach of humanity, of this country as well countries dependent upon pharmacy from India. ${ }^{24}$

When Novartis filled for application, at that time, Indian Patent act was at a transitional phase as India became signatory of the TRIPS agreement. Several amendments took place in compliance with the TRIPS agreement, out of which the amendment of the year 2005 was a significant one as it was by this amendment patent would now be granted for pharmaceutical products. When the assistant controller considered the application, it rejected it as the invention was not considered to be "new", and was "obvious to the person skilled in the art" 25

It is pertinent to note that, at the time when the applellant filed application for patent, India's patent regime underwent enourmous changes. Before the amendment of the year 2005, section 5 of patent act, 1970 barred the grant of patent to any substance inetended or capable of being used as medicine, food or drugs. It was only after the patent (amendement) act, 2005; and country's compliance with the TRIPS agreement, the product patent was provided in the country. Hence, section 5 being deleted. ${ }^{26}$

After the rejection form the Assistant Controller of the Patent Office, Novartis filled for writ petitions before the madras high court in order to seek declaration from the court, that sec 3(d) of patents act, 1970 is unconstitutional as

\footnotetext{
${ }^{19}$ Nopr.niscair.res.in/bitstream/123456789/19550/1/jipr\%/203\%282\%29\%2059-67.pdf (last visited on 22:00 pm)

$201^{\text {st }}$ april, 2013; civil appeal no:2706-2716 of 2013

${ }^{21} \mathrm{https} / / /$ www.indiankanoon.org/doc/165776436 (last visited on 9th march, at about 22:28)

22 Lessons from SADC from the indian case of AG Novartis v Union of india eISSN 1727-3781, 2015 volume 18 no.4

${ }^{23} \mathrm{https} / / / \mathrm{www}$. indiankanoon.org/doc/165776436 (last visited on 9th march, at about 22:28 pm)

${ }^{24}$ Ibid

${ }^{25}$ Boston college international and comparative law review, volume 39, isuue:3, article: 5, kevin tarsa; boston college law school.

${ }^{26}$ Supra
} 
it is violative of article $14^{27}$. Thereafter the high court transferred the petitions to IPAB ${ }^{28}$. The IPAB affirmed the decision given by the Assistant Controller and therefore rejected the petition of Novartis. However, IPAB ruled that Novartis could receive process patent for producing Imatinib in beta crystalline form. Aggrieved by the order of IPAB, Novartis went to the Supreme Court under article $136 .{ }^{2930}$

\section{Judgement by the Supreme Court}

The issue raised before the Supreme Court of India was to determine whether the product qualifies as a new invention and involves inventive step, that is criteria of sec 2(1)(j) and (ja), and further, even if the product qualifies as new, can its patentability be rejected on the grounds of section 3(d)?

The court determined the true meaning of section 3(d), which sought to prevent "ever greening" and to provide lifesaving drugs to all the sections of the society and the fulfilment of state's objective, that is, to provide good health care to all of its citizens.

It was aptly cited by the bench in its judgement that, while harmonizing the patent law of the country along with its compliance with the TRIPS agreement, the indian legislature strove to balance between its obligations under the international treaties well as its commitment to promote good health care and promote public health considerations. ${ }^{31}$

It was submitted on the behalf of appellant that once a product satisfies criteria of $\sec 2(1)(j)$ and $(j$ a) of the act, it satisfies the patentability, and therefore section 3(d) of the patents act, 1970 will not be applicable. ${ }^{32}$

The Supreme Court contended that ${ }^{33}$; beta crystalline from of imatinib mesylate is a new form of "known substance", of which efficacy was well known and therefore it attracts sec 3(d). This means that all the pharamological properties of beta crystalline form of imatinib mesylte are equally possessed in imatinib in free base form or its salt, therefore the product does not have enhanced efficacy over the known substance.

Section $3 \mathrm{~d}$ of the act ${ }^{34}$, states in the explanation that, any salt, Easters, other derivatives of a known substance shall be considered same substance, unless and until they have "enhanced efficacy". Therefore, for the purposes of any drugs or medicenes, the efficacy, must be "therauptic effiacacy", which means the effect must be on the body. ${ }^{35}$ In this regard, the additional beneficial features of beta crystalline form of imatinib mesylate do not have any therauptic or beneficial effect on the body. ${ }^{36}$

Section 2(1)(j) of the act defines invention, which means that the subject matter for which the patent is required must be better than what is in existence. However, in case of pharmaceuticals, the product must be new in addition to efficacy, as laid down in explanation of section 3(d).

The court also highlighted that, in US the drug "gleevac" that is, imatinib mesylate, came to the market in 2001. While during the time, the appleant's application was pending, still the appealant was provided with "exclusive marketing rights" and the drug was in sale in India, in 2003, and the pacakaging of the drug too specified "imatinib mesylate", and it was nowhere mentioned "beta crystalline" form; that is the subject matter of the patent, in the instant case.

Therefore it was contended by the court, that the attempt of the applellant was mere to receive the patent and therefore the appeal of the Novartis was dismissed along with cost.

\footnotetext{
${ }^{27}$ Right to equality

${ }^{28}$ Intellectual property appellate board

${ }^{29}$ Special leave petition

${ }^{30}$ Boston college international and comparative law review, volume 39 , issue 3 , article 5

${ }^{31} \mathrm{https} / / / \mathrm{www}$. indiankanoon.org/doc/165776436 (para 66)

${ }^{32} \mathrm{~L}$ ndvolu, lessons from SADC from the indian case of AG Novartis

${ }^{33}$ Novartis case, para 161

${ }^{34}$ Patents act, 1970

${ }^{35}$ Novartis case, para 181

${ }^{36}$ Novartis case, para 187
} 


\section{Conclusion:-}

The paper attempts to clarify the concept of novelty in India and US. And critically analyses the case of AG Novartis. This paper thus attempts to summarise that novelty is one of the most important criteria for determination of patentability in India as well as US. Although novelty is not defined specifically in any of the patent laws of both the countries, yet it plays a crucial role in grant of patent.

Moving further, the paper crtically analyses the judgement of the Supreme Court in the novartis case. After the patent (amendment) act, 2005, India's patent regime underwent a complete change and result of this amendment the "pharmaceutical" patents were now being provided. This case was decided by the court by crtically defining and applying section 2 (1) (j) and ( $\mathrm{j}$ a) and also discussed the applicability of section 3 (d) of the patents act, 1970. The judiciary seems to make a harmonious balance between the patentability and "evergreening" of "life-saving drugs" as well as the commitment of the state to provide such medicenes at a reasonable rate. 